\title{
SPECIES COMPOSITION AND GROWTH-TEMPERATURE CHARACTERISTICS OF COLIFORMS IN RELATION TO THEIR SOURCES
}

\author{
AKIRA HIRAISHI ${ }^{1}$ AND SUSUMU HORIE \\ Department of Food Science and Technology, Tokyo University of \\ Fisheries, Minato-ku, Tokyo 108, Japan
}

(Received November 8, 1981)

\begin{abstract}
Species composition and growth-temperature characteristics of coliforms isolated from several types of environmental samples were investigated. It was possible to divide these isolates into eight distinct groups, six species groups and two unidentified, on the basis of their biochemical properties. The isolates included in the unidentified groups, giving IMViC reactions of --++ and -+-+ , were tentatively termed "typical psychrotrophic coliform (TPC)" bacteria because of their ability to grow at $1^{\circ}$. The TPC bacteria and Citrobacter freundii constituted the normal coliform flora of mountain soil and stream water samples. In contrast, Escherichia coli and Klebsiella pneumoniae were major predominant coliforms in polluted river water and sewage samples, the former being most common in human feces samples. In testing the growth response at different temperatures, the isolates of $E$. coli and the TPC bacteria showed relatively constant temperature preferences regardless of origin, whereas those of other coliform members gave varied results dependent upon their sources. The results provided circumstantial evidence that population densities of coliforms able to grow in EC broth at $43^{\circ}$ and above but not in ordinary nutrient broth at $5^{\circ}$ within 7 days of incubation in the environment are directly proportional to the degree of potential fecal contamination.
\end{abstract}

The coliform bacteria are well established as indicators of hazardous fecal contamination of water and food $(1,2)$. Apart from Escherichia coli, a member of this group, these bacteria occur frequently in areas apparently free from obvious fecal contamination, although all coliforms were once thought of as being of fecal origin (3). Thus, the sanitary significance of coliforms not related to fecal sources has been and still is of major concern, with much interest being directed

1 Present address: Department of Biology, Faculty of Science, Tokyo Metropolitan University, Setagaya-ku, Tokyo 158, Japan. 
toward their identity and potential pathogenicity.

There are a number of reports in the earlier literature that refer to an association of Aerobacter species with nonfecal materials such as soil (4-8) and plants $(7,9-12)$, although the genus of Aerobacter has been rejected and replaced with Klebsiella and Enterobacter (13-15). Also, the so-called intermediates have been reported to constitute the normal coliform flora of undisturbed soil and sites remote from potential polluting agents $(7,16-18)$. Usually, previous investigators classified their isolates on the basis of the results of four tests: indole, methyl red, Voges-Proskauer, and citrate, represented by the mnemonic IMViC. However, the taxonomic differentiation of coliforms by IMViC tests alone has remained ambiguous, especially between the genera Kiebsiella and Enterobacter (19), both of which typically exhibit the --++ IMViC pattern. Besides, Klebsiella isolates are highly variable with respect to IMViC reactions (19-22). During the past decade, attempts have been made to identify isolates with further biochemical testing, such as with amino acid decarboxylases, and Klebsiella pneumoniae has increasingly been isolated from natural environments (20-24). This increase in published instances of the isolation of $K$. pneumoniae from the environment is partly because the taxonomic confusion with Aerobacter has been cleared up. Nevertheless, data on the species distribution of coliforms in areas not exposed to human and animal life are limited due to the former classification being on the basis of IMViC reactions.

Among a number of approaches used to estimate the sanitary significance of coliforms in the environment, the importance of temperature limits for growth, as well as that of the fecal coliform (FC) response (gas production at $44.5^{\circ}$ ), has been emphasized. BURMAN (25) reported that most coliforms of fecal origin, in contrast to those of nonfecal origin, grew at $42^{\circ}$ and suggested that differentiation of coliforms by determining temperature preferences would provide more reliable evidence of fecal origin than IMViC typing. Several workers stated that the isolation of FC-positive $(26,27)$ or thermotolerant (ability to grow at $44.5^{\circ}$; 22) Klebsiella organisms from the environment would indicate their fecal/clinical origins. In addition, psychrotrophic coliforms characterized by their ability to multiply at $5^{\circ}$ have been reported to constitute a significant proportion of coliforms in soil and stream water in areas remote from human life $(28,29)$. Chilled marine fish (30) and raw oysters (31) have been constant sources of such psychrotrophic coliforms as well.

The present study, therefore, was designed to compare the species composition and growth-temperature characteristics of coliforms in relation to their sources and to estimate the sanitary significance of each coliform member on the basis of their habitats and growth-temperature characteristics. 


\section{MATERIALS AND METHODS}

Samples. Soil samples were collected from the mountainous area located around the Tokyo-Yamanashi prefectural border, where the soil was considered free from potential human contamination. These samples were taken by scraping away approximately $2 \mathrm{~cm}$ surface soil with sterile spoons and transferring into sterile glass bottles. All soil samples were either examined promptly upon return to the laboratory or were stored at $5^{\circ}$ for periods of 15 to $20 \mathrm{hr}$ before plating. Mountain stream water and polluted river water samples were collected from several locations on the Tamagawa River and its branches in Tokyo. Raw sewage samples were obtained at the Shibaura sewage treatment plant in Tokyo. The water samples were taken in sterile polyethylene bottles and stored in an insulated cooler from the time of collection until plating, usually not more than $6 \mathrm{hr}$. Feces samples were obtained from healthy individuals aged 20 to 63 and were plated within $24 \mathrm{hr}$.

Enumeration and isolation procedures. Desoxycholate agar (DA; Eiken) was used as the selective medium for enumerating coliforms. For plating, $10 \mathrm{~g}$ portions of soil samples were homogenized at high speed for $1 \mathrm{~min}$ in $90 \mathrm{ml}$ of sterile, phosphate-buffered saline (1), and the resultant homogenates were allowed to settle for $15 \mathrm{~min}$. Samples of 0.1 and $1 \mathrm{ml}$ of the supernatant obtained were mixed with liquid DA tempered to 45 to $50^{\circ}$ in standard petri dishes. In addition, $10 \mathrm{ml}$ samples of the supernatant were filtered through Millipore membranes (HAWG047S0) with an average pore size of $0.45 \mu \mathrm{m}$ which were then placed on DA solidified in petri dishes. Coliforms in mountain stream water samples were enumerated by the membrane filter technique as above; 10 to $200 \mathrm{ml}$ quantities of these samples were filtered through the membranes. Polluted river water and sewage samples were prepared for testing by serial dilution with sterile, phosphate-buffered saline, and $1 \mathrm{ml}$ quantities of appropriate dilutions were plated with liquid DA. Feces samples were homogenized as above at a 1:100 dilution in sterile, phosphate-buffered saline. The resultant homogenates were diluted serially and plated using the agar-pore plate method. All inoculated plates were overlaid $15 \mathrm{~min}$ after plating with an additional $7 \mathrm{ml}$ of the same medium. The DA overlay plates were made in duplicate for individual samples and incubated at 30 and $35^{\circ}$ for 22 to $24 \mathrm{hr}$ before counting. Typical red colonies recovered in the DA overlay incubated at 30 and $35^{\circ}$ were presumptively recorded as $30^{\circ}$-total coliform (30-TC) and $35^{\circ}$-total coliform (35-TC) bacteria, respectively.

Presumed coliform colonies were subjected to the completed test based on the scheme of HoriE et al. (29). For individual samples, 10 to 30 colonies recovered in the DA overlay were picked randomly and inoculated into brilliant green bile lactose broth (Eiken) tubes. After incubation for 24 to $72 \mathrm{hr}$, the tubes positive for gas production were streaked on eosin methylene blue agar (Eiken) to ensure cultural purity. Well-isolated colonies on that medium were re-inoculated into lactose broth (polypepton (Daigo), $10 \mathrm{~g}$; meat extract (Mikuni), 
$5 \mathrm{~g}$; lactose, $5 \mathrm{~g}$; $0.2 \%$ bromotymol blue solution, $15 \mathrm{ml}$; distilled water, $1,000 \mathrm{ml}$; $\mathrm{pH}$ 7.3) and then incubated for 24 to $72 \mathrm{hr}$, followed by confirmation of acid and gas production. Gas-producing cultures in lactose broth were transferred onto nutrient agar (Eiken) and tested for morphology, gram reaction (2), catalase (32), and cytochrome oxidase (33). Finally, gram-negative, rod-shaped, asporogenous isolates that were catalase-positive and oxidase-negative were recorded as completed coliforms (30- and 35-TCs). All culture media were incubated at $30^{\circ}$.

Biochemical testing for identification. Cultures grown in nutrient broth (Eiken) at $30^{\circ}$ for 16 to $24 \mathrm{hr}$ were used for biochemical tests. Unless otherwise indicated, all test media were incubated at $30^{\circ}$ without shaking and final readings were taken after 6 days' incubation. IMViC reactions and hydrogen sulfide production were determined as described elsewhere (30). Motility was determined in the medium of BALL and SELLERS (34) incubated for $48 \mathrm{hr}$, and concurrently, gelatin liquefaction was recorded with this medium. The type of flagellation was determined by electron microscopy. Tests for lysine and ornithine decarboxylases and arginine dihydrolase were conducted using Møller's medium (Difco). The mode of glucose metabolism was determined in the oxidationfermentation medium of HUGH and LEIFSON (35). Acid production from other carbohydrates was determined in the same medium containing each of the $1 \%$ filter-sterilized carbohydrates. Hydrolysis of alginate, pectate, Tween 80, and tributyrin was determined by the methods of DAVIS and EwING (36), PATON (37), Sierra (38), and Hugo and Beveridge (39), respectively. Hydrolysis of starch and deoxyribonucleic acid was recorded on nutrient agar containing $1 \%$ soluble starch and DNase test agar (Eiken), respectively. These tests for the hydrolytic activities were held for 10 days before being discarded as negative. Yellow pigment production was observed for cultures grown on nutrient agar, mannitol yeast extract agar (32), and nutrient skim milk agar (40) incubated at $25^{\circ}$. Tests for nitrate reduction in nitrate broth, phenylalanine deamination and malonate utilization in phenylalanine malonate medium, urea decomposition on Christensen's agar, gluconate oxidation, and growth in $\mathrm{KCN}$ broth were carried out by the methods described by SAKAZAKI (32). The isolates were classified by comparing the reactions obtained with those described by SAKAZAKI (15).

Determination of growth-temperature characteristics and FC response. Cultures grown in nutrient broth at $30^{\circ}$ for 16 to $18 \mathrm{hr}$ were inoculated into meat extract glucose (MG) broth (polypepton (Daigo), $10 \mathrm{~g}$; meat extract (Mikuni), $3 \mathrm{~g}$; sodium chloride, $3 \mathrm{~g}$; glucose, $10 \mathrm{~g}$; distilled water, $1,000 \mathrm{ml} ; \mathrm{pH} 7.3$ ) and into EC broth (Eiken). MG broth tubes were incubated in air-cooled incubators at 1 and $5^{\circ}$ for 10 and 7 days, respectively, and in constant-temperature water baths at 37 and $40^{\circ}$ for $24 \mathrm{hr}$. EC broth tubes were incubated in water baths at 43 and $44.5^{\circ}$ for $24 \mathrm{hr}$. Temperature fluctuations in the air incubators and water baths were \pm 0.5 and $\pm 0.1^{\circ}$, respectively, of each set temperature. Visible cultural 
turbidity in the test tubes was taken as evidence of growth. The positive FC response of cultures was confirmed by their ability to grow and produce gas in EC broth at $44.5^{\circ}$.

\section{RESULTS}

\section{Enumeration}

Table 1 shows the results of the enumeration of coliforms in different samples. Relatively low coliform contents $\left(<10^{3}\right.$ per $\mathrm{g}$ or $\left.100 \mathrm{ml}\right)$ were recorded for mountain soil and stream water samples, in which 30-TC counts were usually higher than 35-TC counts. Polluted river water, sewage, and human feces samples gave consistently high average coliform counts of the order of $10^{5}, 10^{7}$, and $10^{8}$ (per $100 \mathrm{ml}$ or g), respectively, with no marked difference in the count between 30- and 35-TCs. Of the persumed coliforms recovered from the environmental samples, 19 to $53 \%$ were negatives for the completed test and were chiefly composed of anaerogenic E. coli, Citrobacter spp., and Erwinia-like bacteria (data not shown).

\section{Biochemical reactions and identification}

During the course of this study, 2,493 isolates were obtained from the five sources, and 2,372 (95\%) thereof were divided into eight distinct groups, six species groups and two unidentified, on the basis of their biochemical reactions. Table 2 summarizes these results, with the data on the growth response at different temperatures of the isolates. All of the isolates were gram-negative, non-sporing, straight rods which produced catalase but not oxidase, fermented glucose in the O-F medium, formed acid and gas from lactose, and reduced nitrate to nitrite. Six (I-IVb) of the eight groups listed in the table were readily identified as being of the following species: Escherichia coli, Citrobacter freundii, Citrobacter diversus, Klebsiella pneumoniae, Enterobacter cloacae, and Enterobacter aerogenes. The isolates included in the remaining groups $(\mathrm{V}, \mathrm{VI})$ listed in the final two columns

Table 1. Enumeration of coliforms in different samples.

\begin{tabular}{|c|c|c|c|c|c|c|c|}
\hline \multirow[t]{2}{*}{ Sample type } & \multirow[t]{2}{*}{$\begin{array}{l}\text { No. of } \\
\text { samples } \\
\text { tested }\end{array}$} & \multicolumn{2}{|c|}{ Recovery $(\%)^{a}$} & \multicolumn{2}{|c|}{$\begin{array}{l}\text { Log mean of } \\
\text { presumed } \\
\text { coliform counts } \\
\text { per g or } 100 \mathrm{ml}\end{array}$} & \multicolumn{2}{|c|}{ Accuracy $(\%)^{b}$} \\
\hline & & 30-TC & $35-\mathrm{TC}$ & 30-TC & $35-\mathrm{TC}$ & 30-TC & $35-\mathrm{TC}$ \\
\hline Mountain soil & 36 & 94 & 83 & 2.34 & 2.04 & 47 & 58 \\
\hline Mountain stream water & 37 & 99 & 96 & 2.53 & 1.76 & 74 & 68 \\
\hline Polluted river water & 12 & 100 & 100 & 5.34 & 5.34 & 71 & 73 \\
\hline Raw sewage & 8 & 100 & 100 & 7.11 & 7.18 & 80 & 81 \\
\hline Human feces & 43 & 100 & 100 & 8.23 & 8.26 & 100 & 100 \\
\hline
\end{tabular}

a Percentage of samples from which recovered.

$b$ Percentage of colonies positive for the completed test. 
Table 2. Characteristics of coliform isolates differentiated by biochemical tests.

\begin{tabular}{|c|c|c|c|c|c|c|c|c|}
\hline \multirow{2}{*}{ Characteristic } & \multicolumn{8}{|c|}{$\%$ Isolates positive } \\
\hline & Group I & IIa & $\mathrm{IIb}$ & III & IVa & $\mathrm{IVb}$ & V & VI \\
\hline Indole production & 97 & 5 & 100 & 27 & 1 & 0 & 0 & 0 \\
\hline Methyl red & 100 & 100 & 100 & 15 & 2 & 0 & 0 & 100 \\
\hline Voges-Proskauer & 0 & 0 & 0 & 98 & 100 & 100 & 100 & 0 \\
\hline Citrate (Simmons) & 0 & 100 & 100 & 100 & 100 & 100 & 100 & 100 \\
\hline Motility & 96 & 100 & 100 & 0 & 100 & 95 & 99 & 98 \\
\hline $\begin{array}{l}\text { Pigmentation } \\
\text { (nutrient agar) }\end{array}$ & 0 & 0 & 0 & 0 & 0 & 0 & 1 & 9 \\
\hline $\mathrm{H}_{2} \mathrm{~S}$ production & 1 & 94 & 0 & 0 & 0 & 0 & 0 & 0 \\
\hline Lysine decarboxylase & 97 & 0 & 0 & 100 & 0 & 100 & 0 & 98 \\
\hline Ornithine decarboxylase & 93 & 12 & 100 & 0 & 100 & 100 & 1 & 100 \\
\hline Arginine dihydrolase & 26 & 34 & 25 & 1 & 100 & 0 & $72 d$ & 0 \\
\hline Phenylalanine deaminase & 0 & 0 & 0 & 0 & 0 & 0 & $92 \mathrm{w}$ & 0 \\
\hline Malonate utilization & 0 & 2 & 100 & 100 & 73 & 100 & 100 & 100 \\
\hline Gelatin liquefaction & 0 & 0 & 0 & 2 & $94 d$ & $14 d$ & $76 \mathrm{~d}$ & 0 \\
\hline Urease (Christensen) & ND & ND & ND & 99 & 82 & 5 & 0 & 0 \\
\hline Tween 80 hydrolysis & ND & ND & ND & 0 & 0 & 0 & $98 d$ & 98 \\
\hline \multicolumn{9}{|l|}{ Growth in MG broth at: } \\
\hline $1^{\circ}$ (within 10 days) & 0 & 0 & 0 & 0 & 0 & 0 & 100 & 100 \\
\hline $5^{\circ}$ (within 3 days) & 0 & 5 & 0 & 0 & 8 & 5 & 100 & 100 \\
\hline $5^{\circ}$ (within 5 days) & 0 & 83 & 64 & 23 & 72 & 24 & 100 & 100 \\
\hline $5^{\circ}$ (within 7 days) & 0 & 97 & 76 & 44 & 81 & 24 & 100 & 100 \\
\hline $37^{\circ}$ & 100 & 100 & 100 & 100 & 100 & 100 & 73 & 98 \\
\hline $40^{\circ}$ & 100 & 100 & 97 & 99 & 98 & 100 & 0 & 0 \\
\hline \multicolumn{9}{|l|}{ Growth in EC broth at: } \\
\hline $43^{\circ}$ & 100 & 43 & 21 & 57 & 20 & 76 & 0 & 0 \\
\hline $44.5^{\circ}$ & 100 & 3 & 15 & 47 & 12 & 48 & 0 & 0 \\
\hline FC response & 93 & 1 & 9 & 19 & 5 & 19 & 0 & 0 \\
\hline No. of isolates & & & & & & & & \\
\hline $30-\mathrm{TC}$ & 581 & 124 & 18 & 168 & 59 & 10 & 220 & 34 \\
\hline $35-\mathrm{TC}$ & 559 & 222 & 15 & 239 & 88 & 11 & 12 & 12 \\
\hline Total & 1140 & 346 & 33 & 407 & 147 & 21 & 232 & 46 \\
\hline Assumed species/group & & & & & & & & \\
\hline I Escherichia coli & & & V & Unident & ied grou & (terme & tentatively & \\
\hline IIa Citrobacter fres & undii & & & TPC grc & ip A) & & & \\
\hline IIb Citrobacter dive & ersus & & VI & Unident & ied grol & (terme & tentatively & \\
\hline III Klebsiella pneur & imoniae & & & TPC grc & ip B) & & & \\
\hline IVa Enterobacter cl & loacae & & & & & & & \\
\hline IVb Enterobacter ae & erogenes & & & & & & & \\
\hline
\end{tabular}

Symbols: d, delayed reaction (after 3 or more days); w, weak reaction; ND, not done. For biochemical reactions for which all isolates were positive or negative, see text. 
Table 3. Biochemical reactions of the TPC bacteria by additional tests.

\begin{tabular}{|c|c|c|c|c|c|c|}
\hline \multirow{3}{*}{ Characteristic } & \multicolumn{6}{|c|}{$\%$ Positive for } \\
\hline & \multicolumn{3}{|c|}{$\begin{array}{l}140 \text { isolates of } \\
\text { TPC group A at: }\end{array}$} & \multicolumn{3}{|c|}{$\begin{array}{l}36 \text { isolates of } \\
\text { TPC group B at: }\end{array}$} \\
\hline & $48 \mathrm{hr}$ & 6 days & 10 days & $48 \mathrm{hr}$ & 6 days & 10 days \\
\hline \multicolumn{7}{|l|}{ Yellow pigment on: } \\
\hline Nutrient agar & 0 & 0 & ND & 11 & 11 & ND \\
\hline $\begin{array}{l}\text { Mannitol yeast } \\
\text { extract agar }\end{array}$ & 6 & 7 & ND & 6 & 6 & ND \\
\hline $\begin{array}{l}\text { Nutrient skim } \\
\text { milk agar }\end{array}$ & 76 & ND & ND & 72 & ND & ND \\
\hline Gluconate oxidation & 64 & ND & ND & 100 & ND & ND \\
\hline Growth in $\mathrm{KCN}$ & 77 & 77 & ND & 81 & 92 & ND \\
\hline \multicolumn{7}{|l|}{ Hydrolysis of: } \\
\hline Starch & 0 & 0 & 0 & 0 & 71 & 78 \\
\hline Alginate & 0 & 0 & 0 & 0 & 0 & 0 \\
\hline Pectate & 0 & 0 & 0 & 0 & 0 & 0 \\
\hline Tributyrin & 0 & 0 & $83 w$ & 86 & 100 & 100 \\
\hline DNA & 2 & 6 & 7 & 0 & 0 & 0 \\
\hline \multicolumn{7}{|l|}{ Acid from: } \\
\hline L-Arabinose & $100 \mathrm{~g}$ & 100 & ND & 100 & 100 & ND \\
\hline L-Rhamnose & 100 & 100 & ND & 100 & 100 & ND \\
\hline L-Sorbose & 0 & 0 & ND & 0 & 0 & ND \\
\hline Cellobiose & 100 & 100 & ND & 6 & 9 & ND \\
\hline Raffinose & 99 & 99 & ND & 53 & 57 & ND \\
\hline Sucrose & 100 & 100 & ND & 0 & 0 & ND \\
\hline Melezitose & 44 & 44 & ND & 0 & 0 & ND \\
\hline D-Adonitol & 0 & 0 & ND & $100 \mathrm{~g}$ & 100 & ND \\
\hline Dulcitol & $100 \mathrm{~g}$ & 100 & ND & $100 \mathrm{~g}$ & 100 & ND \\
\hline Glycerol & 85 & 100 & ND & 92 & 100 & ND \\
\hline D-Mannitol & $100 \mathrm{~g}$ & 100 & ND & 100 & 100 & ND \\
\hline D-Sorbitol & $100 \mathrm{~g}$ & 100 & ND & 100 & 100 & ND \\
\hline Inositol & 0 & 0 & ND & 100 & 100 & ND \\
\hline $\begin{array}{l}\alpha \text {-Methyl-D- } \\
\text { glucoside }\end{array}$ & 0 & $44 w$ & ND & 0 & 0 & ND \\
\hline Salicin & $100 \mathrm{~g}$ & 100 & ND & 100 & 100 & ND \\
\hline Esculin & 100 & 100 & ND & 78 & 92 & ND \\
\hline
\end{tabular}

Symbols: w, weak reaction; $g$, more than $80 \%$ isolates positive for gas; ND, not done.

of the table gave such interesting results as suggested that they would not correspond in detail to any of the established species of the coliform group, although being homogenous in their biochemical reactions. This suggestion was supported by the results obtained in the examination of representative isolates of the two groups for further biochemical reactions (Table 3). Because all of the group V and VI isolates were able to grow at $5^{\circ}$ within at least 3 days of incubation and even at $1^{\circ}$ but not at $40^{\circ}$ and above, they were tentatively termed "typical psy- 


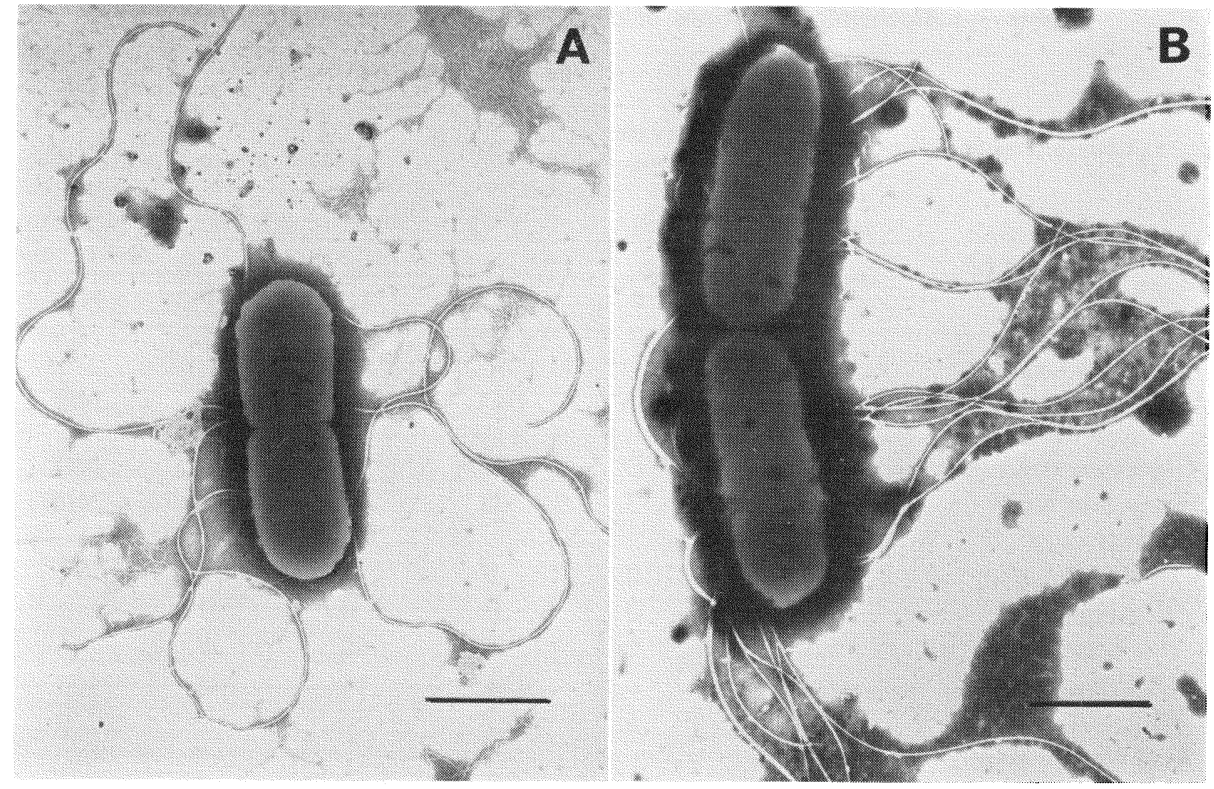

Fig. 1. Electron micrographs of peritrichously flagellated cells of TPC group A (A) and B (B). Scale-bar $=1 \mu \mathrm{m}$.

Cells grown on nutrient agar slants at $30^{\circ}$ for $16 \mathrm{hr}$. Negatively stained with potassium phosphotungstate.

chrotrophic coliform (TPC)" bacteria and the former was designated TPC group A and the latter TPC group B in this study.

With no or few exceptions, the TPC group A isolates (IMViC --++ ) were motile by the use of peritrichous flagella (see Fig. 1-A), decarboxylated neither lysine nor ornithine, produced phenylalanine deaminase, utilized malonate as a sole carbon source, and hydrolyzed Tween 80 and tributyrin but not starch, alginate, pectate, or DNA. The reaction of phenylalanine deaminase was very weak, as the test medium turned faintly green 20 to $30 \mathrm{sec}$ after the addition of the ferric chloride test reagent. Also, the lipolytic activity was barely detectable on the 10-day-old test medium and several isolates lost this activity upon subculture. Acid was produced from arabinose, rhamnose, cellobiose, raffinose, sucrose, dulcitol, glycerol, mannitol, sorbitol, salicin, and esculin. The acid production from arabinose, dulcitol, mannitol, sorbitol, and salicin was accompanied by gas bubble formation in most of the cultures. No acid was produced from sorbose, adonitol, or inositol. The majority produced a yellow, waterinsoluble pigment on nutrient skim milk agar, with considerable variation of the degree of pigmentation, pale yellow being most common, but this property was not clear on nutrient agar or mannitol yeast extract agar. Although the TPC. group A isolates were quite uniform as above, it was possible to separate them into 
Table 4. Biogroups of the TPC group A isolates.

\begin{tabular}{lccc}
\multicolumn{1}{c}{ Characteristic } & \multicolumn{3}{c}{ Biogroup: } \\
\hline Growth at $37^{\circ}$ & 1 & 2 & 3 \\
\hline KCN tolerance & + & + & - \\
Arginine dihydrolase & + & - & $\mathrm{v}$ \\
Gluconate oxidation & + & $\mathrm{v}$ & - \\
Acid from melezitose & + & - & $\mathrm{v}$ \\
Acid from $\alpha$-methyl glucoside & $(+)$ & - & - \\
No. of isolates tested & 61 & 32 & 47
\end{tabular}

Symbols: + , more than $90 \%$ isolates positive; - , more than $90 \%$ isolates negative; $\mathrm{v}, 11-89 \%$ isolates positive; $(+)$, delayed weak reaction.

three biogroups on the basis of growth at $37^{\circ}, \mathrm{KCN}$ tolerance, arginine dihydrolase, gluconate oxidation, and acid production from melezitose and $\alpha$-methyl glucoside as shown in Table 4.

In general, the TPC group B isolates ( $\mathrm{IMViC}-+-+$ ) were motile by the use of peritrichous flagella (see Fig. 1-B), hydrogen sulfide-negative, lysine decarboxylase-positive, ornithine decarboxylase-positive, arginine dihydrolasenegative, phenylalanine deaminase-negative, and malonate-positive. Acid was produced from arabinose, rhamnose, adonitol, dulcitol, glycerol, mannitol, sorbitol, inositol, salicin, and esculin, whereas no acid was produced from sorbose, cellobiose, sucrose, melezitose, or $\alpha$-methyl glucoside, Gas formation was observed simultaneously in most of the test tubes containing adonitol or dulcitol. The activities of Tween esterase and lipase were detected clearly within $48 \mathrm{hr}$ of incubation. Alginate, pectate, or DNA was not hydrolyzed. No $\mathrm{KCN}$ inhibition was observed. The majority were yellow pigmented on nutrient skim milk agar.

\section{Species composition in different samples}

Table 5 shows the species/group composition of coliforms derived from the five sources. TPC group A was the most predominant type $(>40 \%)$ of 30 -TCs in mountain soil and stream water samples, but occurred in small amounts-less than $3 \%$ of the $35-\mathrm{TC}$ isolates obtained from the same samples. About $20 \%$ of 30-TCs found in mountain soil and stream water samples, which might be also considered predominant, were represented by $C$. freundii, which was highest with about $40 \%$ of the 35-TC isolates derived from these sources. Also TPC group B was chiefly encountered in mountain soil and stream water samples. In contrast, E. coli and K. pneumoniae were major predominant types of both 30- and 35 -TCs in polluted river water and sewage samples, comprising 66 to $92 \%$ of the isolates obtained from these samples. E. coli was detected consistently in the overwhelming majority from human feces samples. However, all other genera of the coliform group were found in these samples to some degree, and in two of 


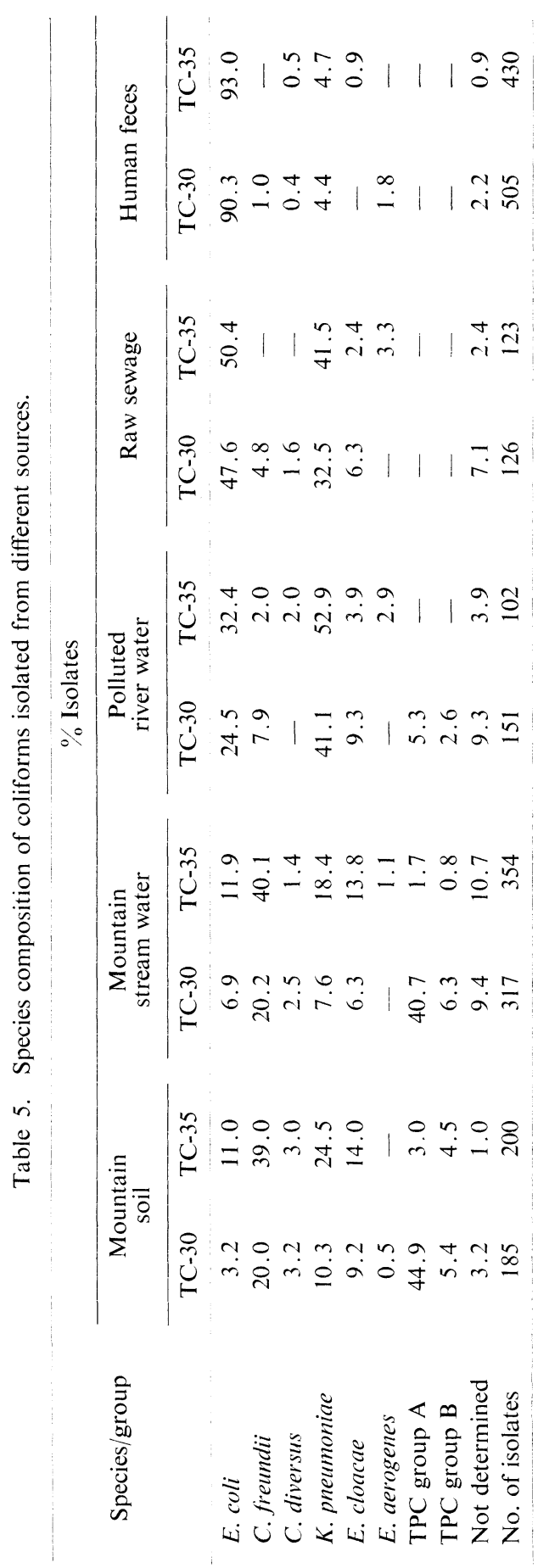


the 43 samples tested $K$. pneumoniae occurred alone (data not shown). In addition, sewage and feces samples were devoid of the TPC bacteria.

Growth-temperature characteristics of coliforms in relation to their sources

In testing the growth response at different temperatures, the isolates of $E$. coli and the TPC bacteria showed relatively constant features; namely, all of the former grew at $44.5^{\circ}$ but not at $5^{\circ}$ while all of the latter grew well at $5^{\circ}$ with a failure to grow at $40^{\circ}$ and above (Table 2). Also, positive FC reactions were produced by most $(93 \%)$ of the E. coli isolates. These results indicate that the growth-temperature characteristics of these coliform types are independent of their origins. On the other hand, the isolates of the other members gave variable results for the growth response at 5,43 , and $44.5^{\circ}$ and for the FC test. Attention therefore was directed to the relationships between these characteristics of the isolates identified as being of the species of Citrobacter, Klebsiella, and Enterobacter and their sources.

As shown in Fig. 2, the greater majority of the Klebsiella and Enterobacter

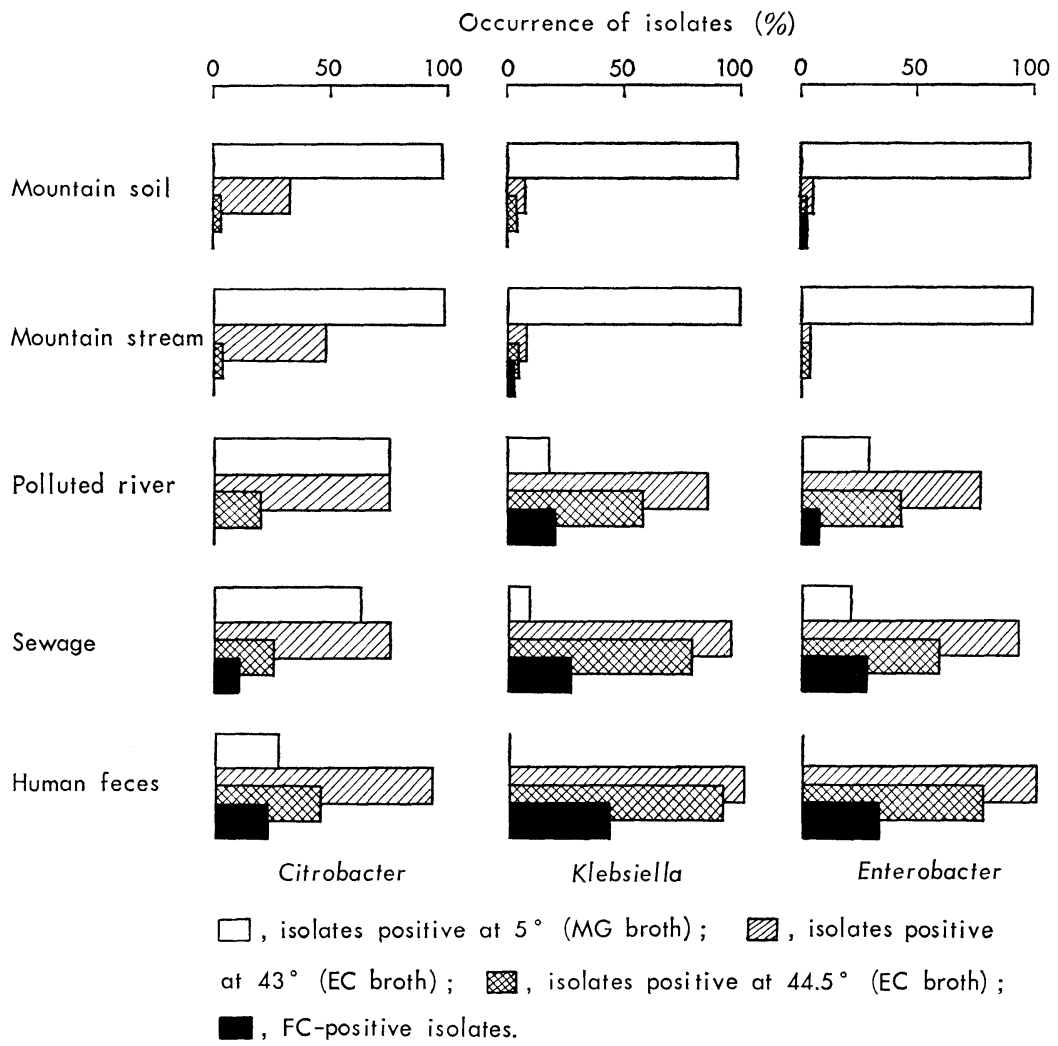

Fig. 2. Growth response at 5,43 , and $44.5^{\circ}$ of some members of coliforms in relation to their sources. 
isolates obtained from mountain soil and stream water samples were psychrotrophic types that grew in MG broth at $5^{\circ}$ but not in EC broth at 43 and $44.5^{\circ}$, whereas thermotolerant types capable of growth at such high temperatures constituted considerable proportions of those derived from polluted river water and sewage samples, with a marked reduction of positives at $5^{\circ}$. Apparently, the occurrence of FC-positive isolates was directly proportional to that of the thermotolerant types. These tendencies were also exhibited by the Citrobacter isolates but were not so pronounced as those shown by the isolates of the former genera. With the exception of the Citrobacter isolates, all of fecal origin grew at $43^{\circ}$ but not at $5^{\circ}$.

Consequently, few psychrotrophic coliforms occurred among the isolates able to grow at $43^{\circ}$ and above during the course of this study.

\section{DISCUSSION}

The present study has demonstrated the existence of two unidentified groups of psychrotrophic coliforms, designated tentatively as TPC groups A and B, respectively. In general, both the TPC group $A$ and $B$ isolates grew at $1^{\circ}$ but not at $40^{\circ}$, produced a non-diffusible yellow pigment on nutrient skim milk agar, fermented dulcitol with gas production, and showed the activities of Tween esterase and lipase, besides the former being weakly positive for phenylalanine deaminase (Tables 2 and 3). These results provide interesting information on the taxonomic positions of the TPC bacteria, since these properties are limited to members of only few groups of the family Enterobacteriaceae. It has been reported that psychrotrophic coliforms usually give the --++ IMViC pattern (28-31, 41-43), strains resembling Serratia liquefaciens, formerly designated as Aerobacter liquefaciens or Enterobacter liquefaciens, being most common $(42,43)$. Lipolytic activity has been chiefly associated with Serratia and Proteus species within Enterobacteriaceae $(15,36)$, the latter being entirely out with the coliform concept. These facts would suggest that TPC group A has some degree of phenotypic similarity to $S$. liquefaciens, but this relationship is discounted on comparing other basic characteristics of the two. Yellow-pigmented bacteria are common among strains belonging to the Erwinia species included in the herbicola group $(40,44-46)$, one of the three clusters within this genus, for which EwING and FIFE (47) proposed the name Enterobacter agglomerans. Also, the organism previously referred to as "yellow-pigmented Enterobacter cloacae" has been placed in a new species Enterobacter sakazakii (48). Interestingly, some strains of the two yellow-pigmented Enterobacter species produce phenylalanine deaminase $(47,48)$, suggesting some resemblance between TPC group A and these species. However, our data indicate that TPC group A differs apparently from E. sakazakii in other basic characteristics, such as ornithine decarboxylase. In view of the experimental evidence so far obtained, the outline of TPC group A as a taxon is 
considered clear, this group seeming to resemble E. agglomerans most closely, although E. agglomerans or the herbicola group is a heterogenous group with significant biochemical diversity $(15,49,50)$. TPC group $\mathrm{B}$, which is also considered to be a distinct group, corresponds to $C$. freundii with respect to IMViC reactions, but the present results would suggest that this group is similar to $E n$ terobacter or Erwinia species rather than $C$. freundii. At any rate, further studies are necessary to pinpoint the exact taxonomic positions of the TPC bacteria.

There is general agreement that the --++ and -+-+ IMViC types constitute a significant proportion of coliforms in areas free from fecal contamination. Analysis of the species distribution as given in this paper (Table 5) indicates that TPC group A and C. freundii are major predominant coliforms in unpolluted areas remote from human life. Likewise, there is no doubt that TPC group $\mathrm{B}$ originates in such areas. Due to few attempts having been made to identify isolates beyond IMViC reactions in the past, it is difficult to interpret previous reports as to the relationships of the reported predominant types in the environment to the TPC bacteria and $C$. freundii, despite the fair agreement existing between their results and ours concerning the occurrence of IMViC types. However, most of the psychrotrophic coliforms that have been reported by HoriE et al. $(28,29)$ to be dominant in mountainous areas are considered identical with the TPC bacteria, in the light of their biochemical properties and habitats.

The data presented here raise the question of whether the TPC bacteria and C. freundii predominating in unpolluted areas are established in the soil and stream water in these areas. As stated by Randall (17), it is difficult to conclude that the coliform types are established in these environments, because of the low population densities thereof that were not of the order expected of bacteria indigenous to such environments. However, it would appear evident that the sources of the coliforms lay elsewhere than in warm-blooded animal feces. For example, E. agglomerans or the herbicola bacteria, probably related to TPC group A, are associated with plants as constituents of the saprophytic flora $(46,47)$, and $C$. freundii or the $-+-+\mathrm{IMViC}$ type has been found as the predominant coliform in the intestinal tract of cold-blooded animals such as freshwater fish (5l), aquarium snails (52), and frogs (53).

The present results (Table 5) also indicate that although ubiquitous in nature, $K$. pneumoniae is rather a predominant coliform in polluted areas apparently associated with fecal contamination. In addition, this organism was second to $E$. coli in frequency of occurrence in human feces, in some cases occurring alone. These findings support to some extent the view of Buttiaux and Mossel (54) that Klebsiella organisms, as well as E. coli, are specific indicators of fecal pollution.

The sanitary significance of $E$. coli, as generally accepted, is unquestionable. Also, the results obtained with the distribution of the TPC bacteria lead us to 
conclude that they would be of no value as fecal indicators. With respect to the sanitary significance of other coliform members, their growth-temperature characteristics may be useful in the estimation thereof. In this study, with few exceptions of Citrobacter isolates, all coliforms of fecal origin were able to grow in EC broth at $43^{\circ}$ but not in MG broth at $5^{\circ}$ within 7 days of incubation, and the incidence of such coliforms with the high temperature preference was evidently higher in polluted river water and sewage samples than in mountain soil and stream water samples (Fig. 2). These data provide circumstantial evidence that population densities of coliforms able to grow in EC broth at $43^{\circ}$ and above but not in ordinary nutrient broth at $5^{\circ}$ within 7 days of incubation in the environment are directly proportional to the degree of potential fecal contamination. In this context, BAGLEY and SEIDLER (26) concluded that there were insufficient data to equate the mere ability of a coliform to grow in EC broth at $44.5^{\circ}$ with its fecal origin. Nevertheless, we prefer to consider that the sanitary significance of coliforms with the high temperature prefernce should not be discounted, even if $\mathrm{FC}$ negative.

One should note that lowering the incubation temperature to $30^{\circ}$ for enumerating coliforms resulted in higher counts than were obtained at $35^{\circ}$ when examining samples taken from unpolluted areas (Table 1). This is probably attributable to the presence of a large number of the TPC bacteria in such areas. To eliminate these coliform types, therefore, presumptive tests for total coliforms should be carried out with incubation at $35^{\circ}$ and above. Furthermore, if these are made at such elevated temperatures as $43^{\circ}$, not only $E$. coli but all coliform members of probable fecal/clinical origins may be recovered from the environment, simultaneously with the elimination of coliforms which are of limited sanitary significance.

We are grateful to K. Saheki, Department of Food Science and Technology, Tokyo University of Fisheries, for the interest shown and encouragement given during this wotk. We also thank T. Yasuda and T. Kobayashi for their technical assistance. Special thanks are made to T. Maruyama, Department of Biology, Tokyo Metropolitan University, for electron micrographs.

\section{REFERENCES}

1) Anon., Shokuhin Eisei Kensa Shishin I, supervised by Kosei-sho, Nippon Shokuhin Eisei Kyokai, Tokyo (1973).

2) American Public Health Association, Standard Methods for the Examination of Water and Wastewater, 14th Ed., American Public Health Association, Inc., Washington, D.C. (1975).

3) L. W. PARr, Bacteriol. Rev., 3, 1 (1939).

4) B. R. Johnson and M. Levine, J. Bacteriol., 2, 379 (1917).

5) C. C. Chen and L. F. Rettger, J. Bacteriol., 5, 252 (1920).

6) S. A. Koser, J. Bacteriol., 9, 59 (1924).

7) A. M. Griffin and C. A. Stuart, J. Bacteriol., 40, 83 (1940).

8) N. Frank and C. E. Skinner, J. Bacteriol., 42, 143 (1941). 
9) E. K. Kline, Am. J. Pub. Health, 25, 833 (1935).

10) S. B. Thomas and J. McQuillin, Proc. Soc. Appl. Bacteriol., 15, 41 (1952).

11) M. H. Frazer, W. B. Reid, and J. F. Malcolm, J. Appl. Bacteriol., 19, 301 (1956).

12) C. L. Duncan and A. R. Colmer, Appl. Microbiol., 12, 173 (1964).

13) S. T. Cowan, Cowan and Steel's Manual for the Identification of Medical Bacteria, 2nd Ed., Cambridge University Press, London (1974).

14) S. T. Cowan, In Bergey's Manual of Determinative Bacteriology, 8th Ed., ed. by R. E. Buchanan and N. E. Gibbons, The Williams and Wilkins Co., Baltimore (1974), p. 290.

15) R. SaKazaki, Chonai Saikin I-IV, Kindai Shuppan, Tokyo (1975-1979).

16) D. A. Bardsley, J. Hyg., Camb., 34, 38 (1934).

17) J. S. Randall, J. Hyg., Camb., 54, 365 (1956).

18) E. E. Geldreich, C. B. Huff, R. H. Bordner, P. W. Kabler, and H. F. Clark, J. Appl. Bacteriol., 25, 87 (1962).

19) L. M. Campbell and I. L. Roth, Int. J. Syst. Bacteriol., 25, 386 (1975).

20) D. W. Duncan and W. E. Razzell, Appl. Microbiol., 24, 933 (1972).

21) C. Brown and R. J. Seidler, Appl. Microbiol., 25, 900 (1973).

22) A. P. Dufour and V. J. Cabelli, J. Water Pollut. Control Fed., 48, 872 (1976).

23) J. M. Matsen, J. A. Spindler, and R. O. Blosser, Appl. Microbiol., 28, 672 (1974).

24) M. D. Knittel, Appl. Microbiol., 29, 595 (1975).

25) N. P. Burman, J. Appl. Bacteriol., 24, 368 (1961).

26) S. T. Bagley and R. J. Seidler, Appl. Environ. Microbiol., 33, 1141 (1977).

27) L. G. Naemura and R. J. Seidler, Appl. Environ. Microbiol., 35, 392 (1978).

28) S. Horie, T. Araki, and K. SAheKi, Shokuhin Eiseigaku Zasshi, 13, 405 (1972).

29) S. Horie, S. Usui, T. KAmishiro, and K. SAHeki, Shokuhin Eiseigaku Zasshi, 16, 324 (1975).

30) K. SAHEKI, S. Horie, and K. KeIno, Shokuhin Eiseigaku Zasshi, 12, 95 (1971).

31) S. Horie, T. Yamada, and K. SAHeki, Nippon Suisan Gakkaishi, 42, 131 (1976).

32) R. SAKAzAKI, Shin-Saikin Baichigaku Koza (Jyo), Kindai Shuppan, Tokyo (1978).

33) Kovács, Nature, 178, 703 (1956).

34) R. J. Ball and W. Sellers, Appl. Microbiol., 14, 670 (1966).

35) R. Hugh and E. Leifson, J. Bacteriol., 66, 24 (1953).

36) B. R. Davis and W. H. EwING, J. Bacteriol., 88, 16 (1964).

37) A. M. Paton, Nature, 183, 1812 (1959).

38) G. Sierra, Antonie van Leeuwenhoek J. Microbiol. Serol., 23, 15 (1957).

39) W. B. Hugo and E. G. Beveridge, J. Appl. Bacteriol., 25, 72 (1962).

40) D. C. Graham and W. Hodgkiss, J. Appl. Bacteriol., 30, 175 (1967).

41) W. D. Schultze and J. C. Olson, Jr., J. Dairy Sci., 43, 351 (1960).

42) M. Haruta, F. Umeki, and S. Shinomiya, Toeiken Nenpo, 18, 195 (1966).

43) J. J. Panes and S. B. Thomas, J. Appl. Bacteriol., 31, 420 (1968).

44) K. Komagata, Y. Tamagawa, and H. Iizuka, J. Gen. Appl. Microbiol., 14, 19 (1968).

45) D. W. Dye, N. Z. J. Sci., 12, 223 (1969).

46) R. A. Lelliott, In Bergey's Manual of Determinative Bacteriology, 8th Ed., ed. by R. E. Buchanan and N. E. Gibbons, The Williams and Wilkins Co., Baltimore (1974), p. 332.

47) W. H. Ewing and M. A. Fife, Int. J. Syst. Bacteriol., 22, 4 (1972).

48) J. J. Farmer, III, M. A. Asbury, F. W. Hickman, D. J. Brenner, and the Enterobacteriaceae Study Group, Int. J. Syst. Bacteriol., 30, 569 (1980).

49) D. J. Brenner, G. R. Fanning, and A. G. Steigerwalt, Int. J. Syst. Bacteriol., 24, 197 (1974).

50) R. Sakazaki, K. Tamura, R. Johnson, and R. R. Colwell, Int. J. Syst. Bacteriol., 26, 158 (1976).

51) E. E. Geldreich and N. A. Clarke, Appl. Microbiol., 14, 429 (1966). 
52) K. H. Bartlett and T. J. Trust, Appl. Environ. Microbiol., 31, 635 (1976).

53) K. H. Bartlett, T. J. Trust, and H. Lior, Appl. Environ. Microbiol., 33, 1026 (1977).

54) R. Buttiaux and D. A. A. Mossel, J. Appl. Bacteriol., 24, 353 (1961). 